\title{
PENINGKATAN MANAJEMEN SUMBER DAYA TENAGA PENDIDIKAN
}

\author{
Maulana Akbar Sanjani \\ STKIP Budidaya Binjai
}

\begin{abstract}
Abstrak
Manajemen sumber daya tenaga pendidikan adalah proses pendayagunaan sumber daya manusia tenaga pendidikan dalam penyelenggaraan organisasi pendidikan untuk mencapai tujuan pendidikan secara efektif dan efisien. Fungsi manajemen dalam sekolah mencakup perencanaan, pengorganisasian, penggerakan dan pengawasan dalam bidang tugas sekolah, yaitu manajemen kurikulum atau pengajaran, personil, kesiswaan, keuangan, sarana dan prasarana, material, dan manajemen hubungan dengan masyarakat. Proses pembinaan sumber daya tenaga pendidikan termasuk guru dapat dilakukan melalui pelatihan guru. Karena pelatihan/penataran guru memberikan implikasi sebagai bentuk dukungan eksternal yang diberikan bagi pengembangan profesional hanya akan efektif bila dikaitkan dengan pengalaman tugas dilapangan dan pengetahuan dan keperluan profesional guru. Setiap guru harus bekerja sama dalam meningkatkan kualitas pendidikan dengan melaksanakan fungsi-fungsi manajemen pendidikan di sekolah, baik manajemen kurikulum/pengajaran, ketenagaan/personalia, keuangan, sarana dan prasarana, maupun kesiswaan yang dirancang kepala sekolah. Demikian pula para manajer atau kepala sekolah harus berfungsi sebagai bagian dari kerja sama dalam lembaga untuk menjamin perubahan dalam lingkungan pendidikan era kekinian. Manajemen peningkatan kualitas guru haruslah memiliki pemimpin pendidikan yang profesional, sebab jika tidak, maka manajemen sekolah tidak akan berjalan dengan baik. Untuk menghasilkan kualitas yang baik maka perlu manajemen yang baik. Perencanaan dan pengembangan efektivitas staf dan sumber daya tenaga kependidikan merupakan syarat esensial bagi pencapaian dan maksimalisasi pencapaian tujuan pendidikan.
\end{abstract}

Kata kunci: Manajemen Sumber Daya Tenaga Pendidikan

\section{PENDAHULUAN}

Secara faktual, tidak bisa dibantah bahwa sumber daya manusia adalah bahagian yang terpenting dari unsur manajemen. Bagaimanapun faktor manajemen merupakan proses pengelolaan dalam organisasi yang mencakup unsur sumber daya manusia, material, uang, metode, pasar dan waktu yang berkontribusi terhadap pencapaian tujuan organisasi. Dalam konteks ini ketersediaan sumber daya manusia atau personil yang profesional dalam suatu organisasi sangat signifikan dalam proses manajemen untuk dijalankan dengan baik. Karena itu, bidang sumber daya manusia harus difungsikan dalam setiap organisasi untuk membantu orang-orang dan organisasi mencapai tujuannya. Dalam perkembangan kini, pendayagunaan sumber daya manusia 


\section{Jurnal Serunai Administrasi Pendidikan \\ Vol.6, No.2, Juni 2018 \\ e-ISSN 2620-9209}

menghadapi banyak tantangan yang muncul dari tuntutan kebutuhan pegawai, organisasi dan masyarakat.

Peningkatan mutu pendidikan nasional ditentukan oleh faktor ketersediaan sumber daya guru profesional pada setiap satuan pendidikan. Bagaimanapun, guru masa depan adalah guru yang ditempa secara berkesinambungan di dalam pusat-pusat pelatihan guru yang bermutu. Karena itu manajemen pendidikan nasional perlu membenahi pusat pelatihan guru, karena keberadaan pusat pelatihan guru sangat menentukan percepatan perbaikan profesi guru seiring dengan implementasi UndangUndang Guru dan Dosen Nomor 14 tahun 2005.

Peningkatan kualitas organisasi sangat tergantung pada peran manajemen. Tegasnya, manajemen hanya akan berfungsi dengan baik manakala dijalankan oleh para manajer dan sumber daya manusia yang berkualitas dan profesional. Fungsi manajemen dalam sekolah mencakup perencanaan, pengorganisasian, penggerakan dan pengawasan dalam bidang tugas sekolah, yaitu manajemen kurikulum atau pengajaran, personil, kesiswaan, keuangan, sarana dan prasarana, material, dan manajemen hubungan dengan masyarakat. Fungsi perencanaan dilaksanakan oleh kepala sekolah beserta staf dan guru-guru dalam merencanakan kegiatan apa saja yang akan dilakukan untuk mencapai tujuan yang ditetapkan. Kemudian dalam tahap pengorganisasian, kepala sekolah menetapkan dan memfungsikan setiap orang dalam sekolah untuk melaksanakan kegiatan. Pada tahap pengerahan, kepala sekolah menggerakkan seluruh orang yang terkait untuk segera bersama-sama melaksanaan kegiatan sesuai dengan tugas masingmasing. Dalam konteks ini ditekankan bahwa kepala sekolah harus bekerja secara akrab dengan masyarakat dan warga sekolah. Disamping harus memiliki manajemen dan kepemimpinan sekolah sebagai tanggung jawab utama dalam melaksanakan tugas pokok dan fungsi, juga sekaligus merancang dan mengarahkan perubahan sekolah ke arah yang lebih baik. Pelaporan siswa menjadi tangggung jawab mereka, menata kegiatan administrasi, kepemimpinan pendidikan, dan memiliki kemampuan berhubungan dengan mayarakat secara lebih baik. Selanjutnya, para guru bertanggung jawab menjalankan kegiatan belajar dan mengajar secara baik (Syafaruddin, 2002).

Setiap guru harus bekerja sama dalam meningkatkan kualitas pendidikan dengan melaksanakan fungsi-fungsi manajemen pendidikan di sekolah, baik manajemen kurikulum/pengajaran, ketenagaan/personalia, keuangan, sarana dan prasarana, maupun 


\section{Jurnal Serunai Administrasi Pendidikan \\ Vol.6, No.2, Juni 2018 \\ e-ISSN 2620-9209}

kesiswaan yang dirancang kepala sekolah. Demikian pula para manajer atau kepala sekolah harus berfungsi sebagai bagian dari kerja sama dalam lembaga untuk menjamin perubahan dalam lingkungan pendidikan era kekinian. Manajemen peningkatan kualitas guru haruslah memiliki pemimpin pendidikan yang profesional, sebab jika tidak, maka manajemen sekolah tidak akan berjalan dengan baik. Untuk menghasilkan kualitas yang baik maka perlu manajemen yang baik.

Proses pembinaan guru adalah rangkaian kegiatan rekrutmen, seleksi, dan penempatan guru. Manajemen seperti ini merupakan manajemen personil guru yang dikelola oleh pemerintah dan lembaga pendidikan yang mengutamakan kualitas. Seorang yang profesional akan terus-menerus meningkatkan mutu karyanya secara sadar melalui pendidikan dan pelatihan. Proses pendidikan dan pelatihan bagi guru secara sederhana dipahami sebagai proses pembinaan. Pembinaan guru adalah serangkaian usaha bantuan kepada guru terutama layanan profesional yang dilakukan oleh kepala sekolah, pengawas untuk meningkatkan kemampuan mengajar yang bermuara kepada peningkatan mutu lulusan. Pengembangan mutu guru atau staf adalah proses memelihara dan melatih dalam rangka meningkatkan kualitas personil tenaga pendidikan. Jadi, diperlukan adanya program pengembangan profesional guru sehingga para guru mendapatkan informasi baru, baik berupa pengetahuan, keterampilan, pembinaan sikap dan komitmen mengajar sebagi tugas profesional yang mulia. Menurut Gueskey dan Huberman dalam Syafaruddin (2002), proses pembinaan sumber daya tenaga pendidikan termasuk guru dapat dilakukan melalui pelatihan guru. Karena pelatihan/penataran guru memberikan implikasi sebagai bentuk dukungan eksternal yang diberikan bagi pengembangan profesional hanya akan efektif bila dikaitkan dengan pengalaman tugas dilapangan dan pengetahuan dan keperluan profesional guru.

Sebagai bagian konstelasi pendidikan nasional, sekolah juga diliputi berbagai problema sumber daya, manajemen dan kepemimpinan. Sekolah perlu bangkit dari keterbelakangan. Pemberdayaan personil menjadi kata kunci untuk mengeliminir berbagai kelemahan. Masa depan pendidikan di Indonesia ditentukan oleh faktor internal dan eksternal. Secara internal, dunia pendidikan masih menghadapi problem pokok rendahnya kualitas sumber daya manusia pengelola pendidikan. Hal ini terkait dengan program pendidikan dan pembinaan tenaga pendidikan yang masih lemah dan pola rekrutmen tenaga pendidikan yang kurang selektif. Secara eksternal, pendidikan 


\section{Jurnal Serunai Administrasi Pendidikan \\ Vol.6, No.2, Juni 2018 \\ e-ISSN 2620-9209}

dipengaruhi globalisasi dan demokratisasi. Modal utama organisasi pendidikan bermakna bahwa staf atau personalia adalah kunci investasi lembaga. Perkembangan kompleksitas lembaga pendidikan bermuara kepada institusi, atau yayasan besar yang memiliki banyak sekolah, atau sekolah yang besar dengan diminati banyak masyarakat. Perencanaan dan pengembangan efektivitas staf dan sumber daya tenaga kependidikan merupakan syarat esensial bagi pencapaian dan maksimalisasi pencapaian tujuan pendidikan.

Pendidikan merupakan bidang kerja yang membutuhkan komitmen pribadi tingkat tinggi semua elemen sumber daya tenaga kependidikan secara profesional. Oleh karena itu, semua pribadi yang terkait dengan pendidikan harus memandang bahwa perubahan pendidikan merupakan keharusan dalam mengantisipasi kebutuhan bangsa, pemerintah, pihak terkait pada masa kini dan mendatang. Bahkan perubahan pendidikan berkenaan dengan masa depan umat manusia dalam menata kehidupan dan kebudayaannya supaya lebih berkualitas dan bermartabat. Tanpa perubahan yang bermakna dengan dirancang oleh manajemen strategik, maka pendidikan menjadi sesuatu yang stagnan, dan diragukan kemampuannya membuat yang baru untuk kemajuan bagi formulasi kebudayaan kontemporer. Semakin baik perencanaan maka akan menghasilkan rencana yang diharapkan. Dalam merespon keperluan peningkatan mutu guru, maka pelaksanaan rencana pengembangan sumber daya guru menjadi faktor penting yang perlu diperhatikan dalam manajemen sekolah. Proses penyusunan rencana merupakan tahap awal dalam pelaksanaan rencana yang diharapkan.

\section{KAJIAN TEORI}

\section{Pengertian Manajemen Sumber daya Tenaga Pendidikan}

Manajemen sumber daya manusia menurut Hasibuan (2009) diartikan oleh sebagai aktivitas pengorganisasian yang melibatkan pengangkatan staf, pelatihan, pengembangan, kompensasi, kesehatan dan kemampuan pegawai serta hubungan pekerja, serta penelitian sumber daya manusia. Manajemen sumber daya manusia dapat diartikan sebagai suatu pendekatan terhadap manajemen manusia. Dalam hal ini dijelaskan bahwa manajemen sumber daya manusia adalah suatu pendekatan strategis terhadap keterampilan, motivasi, pengembangan dan manajemen pengorganisasian sumber daya manusia. Sedangkan menurut Mondy (2008), manajemen sumber daya 


\section{Jurnal Serunai Administrasi Pendidikan \\ Vol.6, No.2, Juni 2018 \\ e-ISSN 2620-9209}

manusia adalah suatu perencanaan, pengorganisasian, pengarahan dan pengawasan atas pengadaan, pengembangan, kompensasi, pengintegrasian, pemeliharaan dan pemutusan hubungan kerja dengan maksud untuk mencapai tujuan organisasi perusahaan secara terpadu. Tujuan manajemen sumber daya manusia menurut Hasibuan (2009) adalah untuk meningkatkan kontribusi produktif dari orang-orang kepada organisasi dalam cara bahwa secara strategis, etika dan tanggung jawab sosial. Tujuan ini membimbing dalam mempelajari dan mempraktikkan manajemen sumber daya manusia yang juga disebut secara umum manajemen personalia. Kajian manajemen sumber daya manusia menjelaskan hubungan usaha sumber daya manusia yang dilaksanakan manajer dan menunjukkan bagaimana personel profesional memberikan kontribusi terhadap usaha tersebut.

Manajemen sumber daya tenaga pendidikan merupakan bagian penting masalah sumber daya manusia dalam penyelenggaraan pendidikan. Manajemen pendidikan juga melibatkan para ahli atau profesional di bidang non kependidikan. Seperti halnya, dalam sekolah ada tujuan yang harus dirumuskan, kebijakan perlu dibuat, program dikembangkan, personil dipekerjakan, fasilitas diperkirakan, segala peralatan diusahakan, dan semua unsur terpisah harus dikoordinasikan. Jadi, dapat disimpulkan bahwa manajemen sumber daya tenaga pendidikan adalah proses pendayagunaan sumber daya manusia tenaga pendidikan dalam penyelenggaraan organisasi pendidikan untuk mencapai tujuan pendidikan secara efektif dan efisien.

\section{PEMBAHASAN}

Kepala sekolah sebagai pimpinan utama sekolah bertanggung jawab melaksanakan pengembangan kebijakan sekolah yang sesuai, menggunakan informasi dan metode terbaik dalam pengembangan sekolah serta staf bertanggung jawab menjamin kebijakan terlaksana dalam cara yang mempermudah kemungkinan mencapai keberhasilan sekolah (Rivai, 2004). Integritas kepala sekolah berhubungan dengan kualitas sekolah. Semakin tinggi kualitas integritas kepala sekolah maka akan semakin tinggi kualitas sekolah. Integritas kepala sekolah merupakan kapasitas kepala sekolah dalam memberikan: 1) komitmen pengabdiannya pada sekolah yang dipimpinnya, tangggung jawab, daya inovasi, kepercayaan; 2) nilai-nilai kejujuran, keyakinan, sikap adil, memelihara dan menepati janji; 3) konsisten dalam tindakan dan keputusannya 


\section{Jurnal Serunai Administrasi Pendidikan \\ Vol.6, No.2, Juni 2018 \\ e-ISSN 2620-9209}

tercermin pada sikap konsekuen dan teguh dalam melaksanakan visi dan misi sekolah. (Martono, 2002)

Kepala sekolah harus memiliki konsep tentang mutu pendidikan. Paling tidak kepala sekolah harus menyusun visi, misi, strategi dan tujuan sekolah dalam menjangkau masa depan, serta kewenangan dan pengawasan dalam melaksanakan pendidikan di sekolah. Strategi peningkatan kualitas guru dimulai dari perubahan manajemen sekolah yang operasional rutinitas kepada manajemen peningkatan mutu secara strategis. Intinya adalah diperlukan pembaharuan dalam konsep mutu, pembiayaan, metode dan pelayanan pendidikan terhadap pelanggan baik kepada murid, guru, orang tua, masyarakat, atau stakeholders. Oleh karena itu, disamping kepemimpinan yang kuat diperlukan peran serta masyarakat untuk peningkatan kualitas guru secara berkelanjutan. Menjadi sekolah yang bermutu secara terpadu berarti memerlukan hubungan erat dengan pihak berkepentingan (stakeholders). Pendidikan memberikan jasa yang berpotensi untuk memecahkan sejumlah persoalan penting masyarakat saat ini. Para profesional pendidikan publik mesti mengembangkan cara baru, cara yang sudah diperbaiki dalam mengajar. Bila sistem pendidikan mutakhir bertahan dalam krisis sekarang ini pertama-tama harus mampu menyelesaikan persaingan yang ada dalam masyarakat. Namun hal yang paling penting adalah bagaimana kepala sekolah mengelola para guru agar guru dapat menjalankan tugastugas mereka dengan baik, sehinggga tujuan pendidikan berjalan sesuai dengan apa yang diinginkan.

Kontribusi terbesar dari manajemen sumber daya manusia khususnya tenaga pendidikan, paling tidak ada 8 hal, yaitu:

1) Membantu organisasi mencapai sasaran,

2) Keterampilan dan kemampuan pegawai menjadi kekuatan pekerjaan secara efisien.

3) Menyediakan bagi organisasi pegawai terlatih dan termotivasi.

4) Meningkatkan terhadap kepuasan kerja sepenuhnya dari pegawai dan aktualisasi diri.

5) Mengembangkan dan mempertahankan kualitas kerja yang membuat pekerjaan dalam organisasi tercapai.

6) Membuatkan komunikasi kebijakan kepada semua pegawai.

7) Membantu untuk memelihara etika kebijakan dan perilaku tanggung jawab sosial. 
8) Mengelola perubahan untuk keuntungan ganda bagi staf, kelompok, perusahaan dan masyarakat. (Sutrisno, 2010)

Para pegawai juga harus menerima kompensasi dalam bentuk gaji, upah atau insentif sepanjang dengan keuntungan pegawai seperti halnya asuransi dan liburan juga harus diperhatikan untuk diterima pegawai. Beberapa imbalan memerlukan pelayanan yang dinyatakan dengan aturan, seperti dalam bentuk jaminan keamanan sosial, kompensasi pekerja, kondisi kerja yang aman, sehat dan pembayaran lembur.

Adapun sasaran manajemen tenaga pendidikan menurut Suwatno (2001) yaitu sebagai berikut:

1. Sasaran Masyarakat, dengan aktivitas pendukung:

- Pemenuhan kebutuhan resmi

- Keuntungan

- Hubungan manajemen dengan persatuan oegawai

2. Sasaran Organisasi, dengan aktivitas pendukung:

- Perencanaan sumber daya manusia

- Hubungan pagawai

- Seleksi

- Pelatihan dan pengembangan

- Penilaian

- Penempatan

- Pemberhentian

3. Sasaran Fungsi, dengan aktivitas pendukung:

- Penilaian

- Penempatan

- Perkiraan

4. Sasaran Personal

- Pelatihan dan pengembangan

- Penilaian

- Penempatan

- Kompensasi

- Perkiraan 


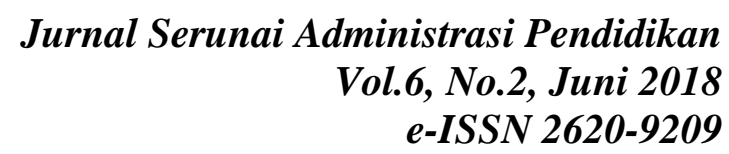

Efektivitas bidang manajemen sumber daya manusia adalah melaksanakan perkiraan dari efektivitas personil untuk menjamin kelanjutan keberhasilan setiap organisasi. Kegiatan membatasi budget secara tradisional adalah satu bentuk dari pengawasan. Hal lain bermakna bahwa kontrol mungkin dilakukan sebagai evaluasi terhadap efektivitas setiap aktivitas dalam mencapai sasaran organisasi.

\section{KESIMPULAN}

Manajemen sumber daya tenaga pendidikan merupakan bagian penting masalah sumber daya manusia dalam penyelenggaraan pendidikan. Manajemen pendidikan juga melibatkan para ahli atau profesional di bidang non kependidikan. Seperti halnya, dalam sekolah ada tujuan yang harus dirumuskan, kebijakan perlu dibuat, program dikembangkan, personil dipekerjakan, fasilitas diperkirakan, segala peralatan diusahakan, dan semua unsur terpisah harus dikoordinasikan. Strategi peningkatan kualitas guru dimulai dari perubahan manajemen sekolah yang operasional rutinitas kepada manajemen peningkatan mutu secara strategis. Intinya adalah diperlukan pembaharuan dalam konsep mutu, pembiayaan, metode dan pelayanan pendidikan terhadap pelanggan baik kepada murid, guru, orang tua, masyarakat, atau stakeholders. Semakin baik perencanaan maka akan menghasilkan rencana yang diharapkan. Dalam merespon keperluan peningkatan mutu guru, maka pelaksanaan rencana pengembangan sumber daya guru menjadi faktor penting yang perlu diperhatikan dalam manajemen sekolah. Proses penyusunan rencana merupakan tahap awal dalam pelaksanaan rencana yang diharapkan.

\section{DAFTAR PUSTAKA}

Hasibuan, M. (2009). Manajemen Sumber Daya Manusia. Jakarta: Bumi Aksara.

Martono. (2002). Mutu Kepemimpinan Kepala Sekolah. Yogyakarta: Andi Press.

Mondy. (2008). Manajemen Sumber Daya Manusia. Alih Bahasa: Bayu Airlangga. Jakarta: Erlangga.

Rivai, V. (2004). Kepemimpinan Kepala Sekolah. Surabaya: PT Sinar Jaya.

Sutrisno, E. (2010). Manajemen Sumber Daya Manusia. Jakarta: Kencana.

Suwatno. (2001). Asas-asas Manajemen Sumber Daya Manusia. Bandung: Suci Press. Syafaruddin. (2002). Manajemen Mutu Terpadu Dalam Pendidikan. Jakarta: Grasindo. Undang-Undang Guru dan Dosen Nomor 14 tahun 2005. 